\title{
PROPERTIES OF PROBIOTICS AND ENCAPSULATED PROBIOTICS IN FOOD
}

\author{
V. Hazal Ozyurt, Semih Ötles ${ }^{\bowtie}$ \\ Food Engineering Department, Faculty of Engineering, Ege University of Izmir \\ 35100, Bornova Izmir, Turkey
}

\begin{abstract}
Probiotics are microorganisms which confer health benefits upon application in sufficiently-high viable cell amounts. Probiotics are typically members of Lactobacillus and Bifidobacterium species commonly associated with human gastrointestinal tracts. In the recent past, there has been a rising interest in producing functional foods containing encapsulated probiotic bacteria. Recent studies have been reported using dairy products like cheese, yogurt and ice cream as food carrier, and non-dairy products like meat, fruits, cereals, chocolate, etc. However, the industrial sector contains only few encapsulated probiotic products. Probiotics have been developed by several companies in a capsule or a tablet form. The review compiles probiotics, encapsulation technology and cell life in the food matrices.
\end{abstract}

Key words: encapsulation, food, Lactobacillus, Bifidobacterium, probiotics

\section{INTRODUCTION}

Probiotics, are mono- or mixed-cultures of live micro-organisms, beneficially affect the health of animals or humans when consumed in sufficient amounts, by improving the properties of the indigenous gastrointestinal flora [Guimaraes et al. 2013, Rehaiem et al. 2014]. Species belonging to Bifidobacterium and Lactobacillus are largely used as probiotics. The latter include Enterococcus, Lactobacillus, Lactococcus, Leuconostoc, Oenococcus, Pediococcus and Streptococcus genera. These genera such as Bifidobacterium and Lactobacillus are common inhabitants of the human gut but functional properties markedly differ within species and strains [Vitali et al. 2012], the yeast Saccharomyces cerevisiae and some Escherichia coli strains are also used as probiotics [Sungsoo-Cho and Finocchiaro 2010].

Scientists first realized in the late 19th century, a wide range of traditional sour milk products had additional benefits apart from prolonged shelf-life and pleasant sensory properties. In 1900, two microbiologists, Tissier and Moro, reported their findings of isolates from the faeces of breast-fed infants. Tissier noted that morphological appearance was similar to those of lactobacilli; however, many of them appeared in bifurcated forms. Thus, he named them Bacillus bifidus. Similarly, Moro postulated that the isolate was derived from the mother's breast and normally resided in the neonate's oral cavity and intestinal content. At the same time, Nobel Laureate Ilya Metchnikoff noticed that Bulgarian peasants had an average lifespan of 87 years. One of the major differences in their lifestyle in comparison with the contemporary diet was a large consumption of fermented milk. Life-span was prolonged by the consumption of sour milk and lactic acid producing bacteria. Metchnikoff's experiments led him to believe that Lactobacillus bulgaricus could

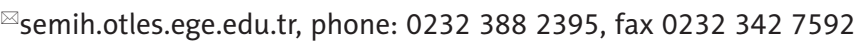


successfully establish itself in the intestinal tract and prevent multiplication and even decrease the number of putrefactive bacteria. Certain strains of Lactobacillus were isolated and found to be capable of colonizing human digestive tract by Minoru Shirota, Japan in 1930. Scientists have continued to investigate possible benefits of bacteria to human health [Vasiljevic and Shah 2008].

\section{SOURCES AND DESCRIPTIONS OF PROBIOTICS}

Probiotics are microorganisms which confer health benefits upon application in sufficiently-high viable cell amounts. Probiotics are commonly associated with human gastrointestinal tracts [Weinbreck et al. 2010]. Some of the descriptions and definitions of probiotics commonly cited over the years in Table 1 [Vasiljevic and Shah 2008].
Species belonging to Bifidobacterium and Lactobacillus are largely used as probiotics. They are also divided two groups as intestinal and vaginal sources [Goktepe et al. 2006].

Bifidobacteria are an important group of probiotic cultures commonly used in fermented dairy products. Bifidobacterium are Gram positive, anaerobic, non motile and non-sporulating organisms. They may have various shapes such as short curved rods, club shaped rods, and bifurcated Y shaped rods [Prasanna et al. 2014]. The species included in the genus Bifidobacterium are 29: $B$. adolescentis, $B$. angulatum, $B$. animalis, $B$. asteroides, $B$. bifidum, B. boum, B. breve, $B$. catenulatum, B. choerinum, B. coryneforme, B. cuniculi, $B$. dentium, B. gallicum, B. gallinarum, B. indicum, B. longum, B. magnum, B. merycicum, B. minimum, B. pseudocatenulatum, B. pseudolongum, B. psychraerophilum, B. pullorum, B. ruminantium, B. saeculare,

Table 1. Probiotic descriptions according to years [Vasiljevic and Shah 2008]

\begin{tabular}{|c|c|}
\hline Year & Description \\
\hline 1953 & $\begin{array}{l}\text { Probiotics are common in vegetable food as vitamins, aromatic substances, enzymes and possibly other substances con- } \\
\text { nected with vital processes }\end{array}$ \\
\hline 1954 & Probiotics are opposite of antibiotics \\
\hline 1955 & Deleterious effects of antibiotics can be prevented by probiotic therapy \\
\hline 1965 & A substance secreted by one microorganism which stimulates the growth of another \\
\hline 1971 & Tissue extract which stimulates microbial growth \\
\hline 1973 & Compounds that build resistance to infection in the host but do not inhibit the growth of microorganisms in vitro \\
\hline 1974 & Organisms and substances that contribute to intestinal microbial balance \\
\hline 1992 & Live microbial feed supplement which beneficially affects the host animal by microbial balance \\
\hline 1992 & $\begin{array}{l}\text { Viable mono- or mixed culture of live microorganism which, applied to animals or man, have a beneficial effect on } \\
\text { the host by improving the properties of the indigenous microflora }\end{array}$ \\
\hline 1996 & Live microbial culture or cultured dairy product which beneficially influences the health and nutrition and the host \\
\hline 1996 & $\begin{array}{l}\text { Living microorganisms which, upon ingestion in certain numbers, exert health benefits beyond inherent beyond basic } \\
\text { nutrition }\end{array}$ \\
\hline 1999 & $\begin{array}{l}\text { Microbial cell preparations or components of microbial cells that have a beneficial effect on the health and well-being of } \\
\text { the host }\end{array}$ \\
\hline 2001 & $\begin{array}{l}\text { A preparation of or a product containing viable, defined microorganism in sufficient numbers, which alter the microflora } \\
\text { in a compartment of the host and by that exert beneficial health effect in this host }\end{array}$ \\
\hline 2002 & Live microorganism which, when administered in adequate amount, confer a health benefit on the host \\
\hline
\end{tabular}


Ozyurt V.H., Ötles S., 2014. Properties of probiotics and encapsulated probiotics in food. Acta Sci. Pol., Technol. Aliment. 13(4), 413-424.

Table 2. Variety of probiotics [Goktepe et al. 2006]

\begin{tabular}{|c|c|c|c|}
\hline \multicolumn{2}{|c|}{ Intestinal bacteria } & \multicolumn{2}{|c|}{ Vaginal bacteria } \\
\hline Lactobacillus acidophilus" "group" & Bifidobacterium adolescentis $^{*}$ & Lactobacillus acidophilus* & Bifidobacterium bifidum \\
\hline L. acidophilus senso strictu & B. angulatum & L. fermentum & B. longum \\
\hline L. animalis & B. bifidum & L. casei & B. infantis \\
\hline L. brevis & B. breve & L. rhamnosus & B. breve \\
\hline L. bunchneri & B. cantenulatum & L. cellobious & B. catenulatum \\
\hline L. crispatus & B. dentium & L. plantarum & B. dentium \\
\hline L. curvatus & B. infantis & L. brevis & \\
\hline L. deLrueckii & B. longum & L. debrueckii & \\
\hline L. fermentum & B. pseudocantenulatum & L. salivarious & \\
\hline L. gasseri & Enterococcus faecalis & L. jensenii & \\
\hline L. johnsonii & E. faecium & L. vaginalis & \\
\hline L. paracasei & Leuc. mesenteroides & L. gassari & \\
\hline L. plantarum & Pediococcus pentosaceus & L. crispatus & \\
\hline L. reuteri & Weissella confusa & & \\
\hline \multicolumn{4}{|l|}{ L. rhamnosus } \\
\hline \multicolumn{4}{|l|}{ L. ruminis } \\
\hline \multicolumn{4}{|l|}{ L. salivarius } \\
\hline L. sakei & & & \\
\hline
\end{tabular}

B. scardovii, B. subtile, B. thermacidophilum, and $B$. thermophilum. In turn two subspecies constitute the species $B$. animalis (subsp. animalis and lactis), B. pseudolongum (subsp. globosum and pseudolongum), and $B$. hermacidophilum (subsp. thermoacidophilum and porcinum), and the species B. longum is subdivided in three different biotypes (longum, infantis, and suis) [Lee and Salminen 2009].

The effectiveness of this organism is related to its ability to colonize the intestinal tract and control undesirable intestinal bacteria. The optimum $\mathrm{pH}$ for the growth of Bifidobacteria is 6.0-7.0 and virtually no growth at below of 4.5 or above of 8.5. The optimum temperatures of growth are $37-41^{\circ} \mathrm{C}$, the minimum are $25-28^{\circ} \mathrm{C}$, and the maximum are $43-45^{\circ} \mathrm{C}$. Some Bifidobacterium cultures used as probiotic are $B$. adolescentis, B. longum, B. infantis, and B. breve [Rivera-Espinoza and Gallardo-Navarro 2010].
Lactic acid bacteria - LAB are usually described as Gram-positive microorganisms, devoid of cytochromes and preferring anaerobic conditions but are aerotolerant, fastidious, acid-tolerant, and strictly fermentative [Lee and Salminen 2009]. At present, more than 125 Lactobacillus species have been identified [Sungsoo Cho and Finocchiaro 2010; Table 2]. The most important genera are: Lactobacillus, Lactococcus, Enterocococcus, Streptococcus, Pediococcus, Leuconostoc, and Bifidobacterium. However, Bifidobacterium shares certain physiological and biochemical properties with typical. Therefore, for practical and traditional reasons, bifidobacteria are still considered a part of the LAB group. Members of the LAB are usually subdivided into two distinct groups based on their carbohydrate metabolism: the homofermentative group which produce lactic acid as principal metabolite and the heterofermentative group which also 
Ozyurt V.H., Ötles S., 2014. Properties of probiotics and encapsulated probiotics in food. Acta Sci. Pol., Technol. Aliment. 13(4), 413-424.

Table 3. Microbial group in the GIT [Goktepe et al. 2006]

\begin{tabular}{|c|c|c|c|c|}
\hline Microbial group & $\begin{array}{l}\text { Stomach } 10^{1}-10^{3} \\
\mathrm{CFU} \cdot \mathrm{ml}^{-1}\end{array}$ & $\begin{array}{l}\text { Dodenum } 10^{1}-10^{4} \\
\mathrm{CFU} \cdot \mathrm{ml}^{-1}\end{array}$ & $\begin{array}{l}\text { Jejunum+Ileum } \\
10^{5}-10^{8} \mathrm{CFU} \cdot \mathrm{ml}^{-1}\end{array}$ & $\begin{array}{c}\text { Colon } \\
10^{9}-5 \cdot 10^{11} \\
\mathrm{CFU} \cdot \mathrm{ml}^{-1}\end{array}$ \\
\hline Actinomyces spp. & & & $10^{4-1} 10^{6}$ & \\
\hline Bacteroides-Prevotella-Porphyromonas group & up to $10^{2}$ & ca. $10^{3}$ & $10^{4-10^{7}}$ & $10^{9-1} 10^{11}$ \\
\hline Bifidobacterium spp. & & & & $10^{9} 10^{10}$ \\
\hline Clostridium spp. & & & $10^{4-1} 10^{5}$ & $10^{8-1} 10^{9}$ \\
\hline Coprococcus cutactus & & & & $10^{7-} 10^{8}$ \\
\hline Enterobacteriaceae & up to $10^{2}$ & $10^{2-1} 10^{4}$ & $10^{3-} 10^{6}$ & $10^{5-10^{7}}$ \\
\hline Enterecoccus spp. & & & $10^{2-1} 10^{4}$ & $10^{3-1} 10^{6}$ \\
\hline Eubacterium spp. & & & & $10^{9-} 10^{11}$ \\
\hline Fusobacterium spp. & & & $10^{3-1} 10^{5}$ & $10^{5-10^{7}}$ \\
\hline Lactobacillus spp. & $10^{1-1} 10^{3}$ & $10^{2-1} 10^{4}$ & $10^{4-1} 10^{6}$ & $10^{5-10^{8}}$ \\
\hline Megamonas hypermegas & & & & $10^{7-10^{8}}$ \\
\hline Megasphaera elsdenii & & & & $10^{7-10^{8}}$ \\
\hline Methanobacteria & & & & up to $10^{9}$ \\
\hline Peptostreptococcus spp. & & & $10^{2-1} 10^{6}$ & $10^{8-1} 10^{9}$ \\
\hline Proteus spp. & & & & $10^{3-1} 10^{6}$ \\
\hline Pseudomonas spp. & & & & $>10^{3}$ \\
\hline Staphylococcil & & & & ca. $10^{3}$ \\
\hline Streptococcus spp. & $10^{1-1} 10^{3}$ & & $10^{3-1} 10^{8}$ & up to $10^{7}$ \\
\hline Veillonella spp. & & & $10^{3-1} 10^{7}$ & $10^{5-10^{8}}$ \\
\hline Yeasts & & & & ca. $10^{3}$ \\
\hline
\end{tabular}

produce ethanol and carbon dioxide. Homofermentative group consists of Lactococcus, Pediococcus, Enterococcus, Streptococcus and some lactobacilli, whereas heterofermentative bacteria include Leuconostoc, Weissella and some lactobacilli [Vasiljevic and Shah 2008].

The growth of $L$. acidophilus occurs at a temperature as high as $45^{\circ} \mathrm{C}$; however, the optimum is found between 35 and $40^{\circ} \mathrm{C}$. The organisms grow in slightly acidic media at $\mathrm{pH}$ of $6.4-4.5$, but growth will stop at a $\mathrm{pH}$ of $4.0-3.6$. This bacterium tolerates from $0.3 \%$ to $1.9 \%$ titrable acidity, with and optimum $\mathrm{pH}$ at 5.5-6.0 [Rivera-Espinoza and Gallardo-Navarro 2010].
L. rhamnosus is a $\mathrm{LAB}$ with probiotic capacity. The growth activity of LAB is affected by fermentation conditions such as $\mathrm{pH}$, temperature, medium composition and other factors [Pimentel-González et al. 2009].

Probiotic microorganisms are mostly of GIT origin. Microbial population are changeable throughout the GIT (Table 3), to $10^{1}$ to $10^{3} \cdot \mathrm{ml}^{-1}\left(\right.$ or $\mathrm{g}^{-1}$ ) in the stomach, $10^{7} \mathrm{ml}^{-1}$ in the jejunum (comprising mainly lactobacilli, Enterobacteriaceae and streptococci), up to $10^{9} \mathrm{CFU} \cdot \mathrm{g}^{-1}$ in the terminal ileum, and ca. $5 \cdot 10^{11} \mathrm{~g}^{-1}$ in the distal colon [Goktepe et al. 2006]. LAB, especially strains of Lactobacillus, are normally found in the human adult gastrointestinal (GI) tract, and have 
Ozyurt V.H., Ötles S., 2014. Properties of probiotics and encapsulated probiotics in food. Acta Sci. Pol., Technol. Aliment. 13(4), 413-424.

Table 4. Fermented food showed probiotic characteristics [Cruz et al. 2009]

\begin{tabular}{|c|c|c|}
\hline Product & Probiotic microorganisms & Substrates \\
\hline Adai & $\mathrm{LAB}$ & cereal, legume \\
\hline Agbelima & Lb. plantarum, Lb. brevis, Lb. fermentum, Leuc. mesenteroides & cassava \\
\hline Atole & LAB & maise \\
\hline Ben-saalga & LAB & pearl millet \\
\hline Boza & $\begin{array}{l}\text { Lb. plantarum, Lb. brevis, Lb. rhamnosus, Lb. fermentum, Leuc. mesenteroides } \\
\text { subsp. dextranium }\end{array}$ & cereals \\
\hline Dosa & Leuc. mesenteroides, Lb. fermentum, Sacch. cerevisiae & rice and bengal gram \\
\hline Idli & Leuc. mesenteroides, LAB, yeast & cereal, legume \\
\hline Ilambazi lokubilisa & LAB & maize \\
\hline Kecap & LAB & wheat, soybeans \\
\hline Kenkey & $\begin{array}{l}\text { Lb. casei, Lb. lactis, Lb. plantarum, Lb. brevis, Lb. acidophilus, Lb. fermentum, } \\
\text { Lb. casei, yeast }\end{array}$ & maize \\
\hline Kishk & LAB & cereal and milk \\
\hline Kisra & Lactobacillus sp., Lb. brevis & sorghum \\
\hline Koko & Lb. fermentum, Lb. salivarius & millet \\
\hline Mahewu & Lb. bulgaricus, Lb. brevis & maize \\
\hline Mawe & Lb. fermentum, Lb. brevis, Lb. salivarius, Sacch. cerevisiae & maize \\
\hline Ngari & $\begin{array}{l}\text { Lactococcus lactis subsp. cremoris, Lactococcus plantanum, Enterococcus } \\
\text { faecium, Lb. fructosus, Lb. amylophilus, Lb. coryniformis subsp. torquens } \\
\text { and Lb. plantarum }\end{array}$ & fish \\
\hline Ogi & Lb. plantarum, Lb. fermentum, Leuc. mesenteroides, and Sacch. cerevisiae & maize \\
\hline Saurkraut & Leuc. mesenteroides, Lactococcus lactis, LAB & cabbage \\
\hline Som-fug & LAB & fish \\
\hline Tarhana & Streptococcus thermophilus, Lb. bulgaricus, Lb. plantarum & $\begin{array}{l}\text { parboiled wheat meal } \\
\text { and yogurt }\end{array}$ \\
\hline Tempeh & LAB, Lb. plantarum & soybean \\
\hline Uji & LAB & $\begin{array}{l}\text { maize, sorghum } \\
\text { cassava, finger millet }\end{array}$ \\
\hline
\end{tabular}

been prevalently used as probiotics, exclusively in fermented dairy products [Tulumoglu et al. 2013].

Probiotic microorganisms are mostly of human or animal origin. The dairy industry, in particular, has found probiotic cultures. Yoghurts and fermented milks are the main vehicles for probiotic cultures [Trabelsi et al. 2013]. New products such as milk-based desserts, powdered milk for newborn infants, icecreams, butter, mayonnaise, various types of cheese are also being introduced in the international market [Cruz et al. 2009]; however, some studies show that strains recognised as probiotics are also found in non-dairy fermented substrates [Martins et al. 2013]. Fermentation has been used to preserve, improve the 
quality or modify the flavor of cereals, fruits, vegetables, legumes and meat. As fermentation process involves mixed cultures such as yeast, LAB and fungi, some of traditional fermented food show probiotic characteristics (Table 4), although the research of these matrices as raw material for probiotic microorganisms is still scarce compared with their dairy counterpart [Rivera-Espinoza and Gallardo-Navarro 2010]. Products made from fruits and vegetables, such as drinks, purées, fermented vegetables, table olives and minimally processed fruit have also been used. Moreover, products containing probiotic bacteria have an everexpanding world market [Martins et al. 2013]. These products can be in the form of capsules or powders to be dissolved in cold drinks, and fermented foods of vegetable origin [Cruz et al. 2009].

\section{HEALTH BENEFITS}

Over the last 20 years there has been an increased interest in the role of probiotic bacteria in human health [Chandramouli et al. 2004]. Probiotics are defined as live microbial feed supplements [Okuro et al. 2013] which beneficially affect the host by improving the intestinal microbial balance [Kima et al. 2008]. Several health benefits are attributed to the ingestion of foods containing probiotic cultures. Some of them proved scientifically and others still requiring further studies in humans [Cruz et al. 2009].

Some of the major benefits of probiotics are: they reduce or eliminate ailments such as colon irritation, constipation and travellers diarrhoea [Rehaiem et al. 2014]. Other health benefits include inhibition of pathogenic bacteria, synthesis of B vitamins, lowering of blood ammonia levels, cholesterol absorption, inhibition of tumour formation [Capela et al. 2006], improving the absorption of calcium [Shi et al. 2013], and improvement of lactose utilization by producing b-galactosidase [Kima et al. 2008], when there are enough probiotics in colon. In order to provide health benefits, it is essential that there is a minimum of one million viable probiotic organisms per gram of a product [Capela et al. 2006], or $10^{7} \mathrm{CFU} \cdot \mathrm{g}^{-1}$ at point of delivery [Amine et al. 2014, Li et al. 2011, Semyonov et al. 2011], or be eaten in sufficient amounts to yield a daily intake of $10^{8}$ CFU [Chávarri et al. 2010], although the numbers vary from strain to strain [Anekella and Orsat 2013].
Many studies have reported that probiotics are very sensitive to adverse environments, and survival rates of probiotics are poor in products. Due to their vast applications in food industries, it is urgent to develop new methods to preserve the viability of probiotics [Shi et al. 2013].

Multiple reports have shown their health benefits on gastrointestinal infections, antimicrobial activity, improvement in lactose metabolism, reduction in serum cholesterol, immune system stimulation, antimutagenic properties, anti-carcinogenic properties, anti-diarrheal properties, improvement in inflammatory bowel disease and suppression of Helicobacter pylori infection by addition of selected strains to food products [Pereira et al. 2011].

The health benefits cannot be predicted for a determined species of microorganisms, and there is no single probiotic strain capable of providing all the benefits mentioned [Cruz et al. 2009].

\section{ENCAPSULATIONS}

Encapsulation may be defined as a process of entrapping one substance (active agent) within another substance (wall material). The substance that is encapsulating is often called the coating, membrane, shell, capsule, carrier material, external phase, or matrix [Nedovic et al. 2011]. The encapsulation technology has been used by the food industry for several years. The number of food compounds has been increasing, for example: flavours, dyes, stabilizers, antioxidants, enzymes, probiotics, lipids, mineral salts and vitamins, among others [Estevinho et al. 2013].

Microencapsulation in which the cells are retained within an encapsulating matrix or membrane [Pimentel-González et al. 2009], has emerged as an alternative for protection of probiotics, providing a particular and convenient micro-environment for the encapsulated microorganism, enhancing their viability, and enabling controlled release of cells in the intestinal tract. Encapsulation technology has been proved to be one of the most effective ways to protect probiotics during processing and subsequent storage. Furthermore, encapsulation systems with control-released ability can deliver probiotics to a specific target and release them at required time [Shi et al. 2013]. The benefits of encapsulation protect probiotics against stress conditions. 
Non-encapsulated probiotic microorganisms may be exposed to high temperatures, low $\mathrm{pH}$, high osmotic pressure and high levels of oxygen during processing and storage of foods [Kailasapathy 2006]. The survival of probiotic organisms is also affected by acid in the stomach and the bile salts in the intestine tract [Capela et al. 2006]. These microcapsules may provide a more suitable anaerobic environment for the susceptible probiotic bacteria [Antunes et al. 2013, Nag et al. 2011], as well as protecting from bacteriophage and harsh enviroment [Heidebach et al. 2009, Jiménez-Colmenero 2013, Makinen et al. 2012], such as freezing and gastric conditions [Pimentel-González et al. 2009] thus reducing cell injury [Antunes et al. 2013].

The capsules should also be able to maintain their entirety through the gastrointestinal tract until they reach colon, where they should comminute and release the probiotic bacteria. Probiotics have been shown liquid based products such as dairy products, while the effect of encapsulation on probiotic survival in dry (low water activity) food products is lower. While it is known that proteins and fats/waxes are good oxygen and moisture barriers, respectively, it is presently not understood whether these compounds are adequate to protect probiotics against these physical factors in dry food matrices. Therefore, protein- and fat-based encapsulates of a commonly used probiotic strain were prepared and the survival of these encapsulates during exposure to different water activities and oxygen levels were compared [Weinbreck et al. 2010].

The functional performance of the microcapsules depends on the morphology, the chemical nature and the surface characteristics of the polymeric shell influenced by the process parameters [Butstraen and Salaün 2014]. A microcapsule consists of a semipermeable or non-permeable, spherical, thin and strong membrane surrounding a solid/liquid core, with a diameter varying from a few microns to $1 \mathrm{~mm}$ [Pimentel-González et al. 2009].

Encapsulation materials, Generally Recognized as Safe (GRAS) ingredients, can be used in food applications [Matalanis et al. 2011, Shi et al. 2013]. Natural polymer based materials are preferred due to their biodegradability, compatibility food grade nature and wide availability [Antunes et al. 2013]. Xanthan gum, gellan gum, starch derivatives, cellulose acetate phthalate, casein, whey proteins [Nualkaekula et al. 2012], chitosan, carboxymethyl cellulose, carrageenan, gelatin, pectin [Pimentel-González et al. 2009] vegetable gum, fats and alginate [Chávarri et al. 2010] can be used as encapsulation material. Alginate as an encapsulating agent is non-toxicity, simplicity in entrapping living microbial cells and low cost. Alginate is also an accepted food additive and can be safely used in foods. The use of alginate is limited due to its low stability in the presence of chelating agents and in acidic conditions below $\mathrm{pH}$ 2.0. The coating of alginate beads and its effectiveness in protecting probiotic bacteria has been extensively studied. Alginate microcapsules has been coasted with chitosan for improving activity [Chávarri et al. 2010]. The most commonly used gum is xanthan, a heteropolysaccharide consisting of polypentasaccharide groups formed from 2 glucose, 2 mannose and 1 glucuronic unit, with its polymer backbone consisting of $1 \rightarrow 4$ linked $\beta$-(D)-glucose units. Microcapsules were produced by the emulsion method in which the discrete water phase, containing xanthan gum was cross-linked with calcium chloride while suspended in oil. This property is advantageous in bacterial applications as the conditions are gentle enough not to damage the bacteria [Cook et al. 2012]. Casein, a milk protein, has been used in a few cases as a water insoluble (below pH 6) matrix for protecting bacteria during gastric transit. Milk proteins are particularly popular as encapsulating materials, while non-milk based materials are less desirable. Skimmedmilk has been utilised in microencapsulation by using rennet to gel the proteins contained in the milk [Cook et al. 2012].

Encapsulating probiotics within a physical barrier has been investigated by many researchers. Encapsulation is considered as a technology of incorporating protective materials into small capsules that can be released at the controlled rate under specific conditions [Chávarri et al. 2010, Shi et al. 2013]. The most used techniques to encapsulate probiotics are extrusion, atomisation or spray drying, emulsion, coacervation and immobilisation in fat and starch granules [Pedroso et al. 2012]. Many encapsulation technologies have been reported extrusion, emulsion method and spray drying technology. Extrusion method probably is the mildest one among all of probiotics encapsulation technologies. These method involves 
dropping hydrocolloid solution with concentrated probiotics into solidifying solution [Shi et al. 2013]. In the emulsion method, a small volume of the cellpolymer suspension is added to a large volume of a vegetable oil such as soybean oil, sunflower oil, canola oil or corn oil. The mixture is homogenized to form a water-in-oil emulsion [Krasaekoopt et al. 2003]. Spray drying is a commonly used microencapsulation technique for probiotic encapsulation [Okuro et al. 2013]. This method involves atomization of an emulsion or a suspension of probiotics and encapsulating agents in a hot air drying chamber, resulting in rapid evaporation of water [Fritzen-Freire et al. 2013].

\section{RECENT ENCAPSULATED DEVELOPMENTS}

Microencapsulation is substantial for the survival of probiotics during storage and their transit through the digestive tract. Probiotics must be encapsulated because they are very sensitive to environmental conditions such as air, moisture, temperature, stomach $\mathrm{pH}$ and bile salt solutions. Addition of microcapsules should not affect the sensory properties of food products [Burgain et al. 2011].

L. bulgaricus was encapsulated in alginate-milk microspheres prepared by Shi et al. [2013]. The tolerance of encapsulated L. bulgaricus to adverse environments such as low $\mathrm{pH}$ ( $\mathrm{pH} 2.0$ and 2.5), high concentration of bile salt $(1.0 \%$ and $2.0 \%)$ and long time storage (1 month), was investigated. This study showed that encapsulation could improve the tolerance of $L$. bulgaricus to adverse environments. However, alginate can provide limited protection to probiotics because alginate microspheres are not stable in acidic environment and have porous structure which allow diffusion of acid in and out of microspheres easily.

Trabelsi et al. [2013] studied to develop the microencapsulation of a L. plantarum TN8 on sodium alginate. The optimal conditions identified were $2 \%$ for sodium alginate, $10^{10} \mathrm{CFU} \cdot \mathrm{ml}^{-1}$ for biomass, and $30 \mathrm{~min}$ for hardening time. When the survival rates of free and microencapsulated L. plantarum TN8 during exposure to artificial gastrointestinal conditions were compared, the encapsulated cells exhibited significantly higher resistances to artificial intestinal juice and artificial gastric juice.
Annan et al. [2008] produced to encapsulate the probiotic $B$. adolescentis $15703 \mathrm{~T}$ with alginate-coated gelatin microspheres. The alginate coated gelatin microspheres in simulated gastric juice ( $\mathrm{pH} \mathrm{2.0,2} \mathrm{h)}$ survive higher numbers due to the buffering effect of intact microspheres. Heidebach et al. [2010] produced casein-based microcapsules for coating two probiotic strains, which differ in their sensitivity against dehydration, $L$. F19 and B. Bb12 during freeze-drying. $L$. F19 survived in significantly higher numbers in the encapsulated state, compared to free cells (proteincell-mixture). Encapsulation improved the survival of $B$. Bb12 during storage for up to 90 days under all tested conditions.

Kim et al. [2008] microencapsulated L. acidophilus ATCC 43121 with sodium alginate. They studied about the effects of microencapsulation on the changes in survival rate of the L. acidophilus ATCC 43121 during exposure to artificial gastrointestinal and on the change in heat susceptibility of L. acidophilus ATCC 43121 during the heat treatment. In addition, cholesterol assimilation and intestinal adhesion of non-encapsulated and encapsulated L. acidophilus ATCC 43121 were also investigated to explore the effect of microencapsulation on health beneficial effect of lactic acid bacteria. Therefore, non-encapsulated cells were completely destroyed when exposed to artificial gastric juice (AGJ) of $\mathrm{pH} 1.2$ and 1.5, while the treatment diminished the viable count of encapsulated samples only by $3 \log$. Encapsulated cells exhibited a significantly higher resistance to artificial intestinal juice (AIJ) and heat treatment than nonencapsulated samples. However, encapsulation did not significantly affect the adherence of L. acidophilus ATCC 43121 onto the human intestinal epithelial cell lines HT-29. The microencapsulation effectively protected the microorganisms from heat and acid treatment in delivering the viable cells to intestine without any significant adverse effect on their functionalities.

Chávarri et al. [2010] used chitosan as a coating material to improve encapsulation of $L$. gasseri (L) and B. bifidum (B) in calcium alginate beads and the prebiotic quercetin $(\mathrm{Q})$ with the objective of enhancing survival of the probiotic bacteria was used. These results indicated that the survival of microspheres with quercetin during storage at $4^{\circ} \mathrm{C}$ was possible, while probiotic bacteria microencapsulated with 
quercetin did not survive. Because of this, quercetin and L. gasseri or B. bifidum were microencapsulated separately. Microencapsulated $L$. gasseri and microencapsulated $B$. bifidum were resistant to simulated gastric conditions ( $\mathrm{pH} 2.0,2 \mathrm{~h})$ and bile solution $(3 \%$, $2 \mathrm{~h}$ ). Consequently, the microencapsulation of L. gasseri and B. bifidum with alginate and a chitosan offered effective media for the microencapsulation of $L$. gasseri and B. bifidum to the colon and maintaining their survival during simulated gastric and intestinal juice.

L. casei ATCC 393 was encapsulated with alginate, chitosan and carboxymethyl chitosan with extrusion method by Li et al. [2011]. Results indicated that alginate-chitosan-carboxymethyl chitosan microcapsules could successfully protect $L$. casei against negative conditions.

Probiotic organisms are typically added either to fresh foods with high water activities and an expected shelf-life of weeks (e.g. yogurt) or to dry products with low water activities $\left(a_{w}<0.25\right)$ and an expected shelf-life of months (e.g. infant formula). For dry products, losses in probiotic viability cause considerable reductions in product shelf-life times [Weinbreck et al. 2010].

Microencapsulated probiotic powder formulation provides a more convenient delivery format compared to wet gelled formulations. Fritzen-Freire et al. [2013] evaluate the viability and the physical properties of BB-12 microencapsulated by spray drying, as encapsulating agent, with the prebiotics inulin, oligofructose, and oligofructose-enriched inulin (at a ratio of $1: 1,200 \mathrm{~g} / \mathrm{L}$ total concentrations). These microcapsules showed a high survival rate of bifidobacteria during storage at the temperatures evaluated.

Ying et al. [2013] were encapsulated L. rhamnosus GG (LGG) with spray drying. Then, capsules were added into apple juice or citrate buffer (pH 3.5) and stored at 4 or $25^{\circ} \mathrm{C}$ over a 5-week period. The LGG was encapsulated by using whey protein isolate (WPI) alone, WPI in combination with a physically-modified resistant starch (RS) at various ratios (4:1, 1:1 and 1:4), or RS alone. Spray dried microencapsulated LGG formulated with WPI or WPI-RS mixtures protected LGG in low $\mathrm{pH}$ environments (pH 3.5 apple juice and citrate buffer) over 5 weeks storage at $4{ }^{\circ} \mathrm{C}$ and were more effective than at high temperature storage $\left(25^{\circ} \mathrm{C}\right)$. Microencapsulated LGG formulations containing WPI or WPI in combination with RS provided better protection to LGG in apple juice and citrate buffer solution than the formulation containing only RS under all storage conditions.

Anekella and Orsat [2013] aimed to microencapsulate a combination of $L$. acidophilus NRRL B-4495 and L. rhamnosus NRRL B-442 in raspberry juice through spray drying. Role of maltodextrin as a carbon source was also assessed for its prebiotic potential. High temperatures during spray drying are harmful to probiotics and can be damaged by sub-lethal thermal shock. Increasing the microencapsulating material concentration increased the survival rate of the probiotics. Non-dairy probiotic foods are becoming popular as they do not pose problems of lactose intolerance.

Most of the products containing probiotic cells have been made to identify new food carriers (Table 5) [Burgain et al. 2011].

Probiotics represent a fast developing field. In past years, probiotics have expanded from the traditional health benefit areas of digestive comfort and immune protection to diverse applications in various, sometimes unexpected, health benefit areas. The use of microencapsulation to enhance the survival rates of probiotic microorganisms in connection with an application in food can be considered to be promising. These methods were optimized towards specific requirements. Many researchers have investigated strategies to improve the storage stability of encapsulated probiotics. Different foods containing encapsulated probiotic cells are present on the market. Belgium group Barry Callebaut produces chocolate containing encapsulated probiotic cells. In some cases, inulin or other prebiotics have been added to probiotics in the manufacturing of the bar called 'Attune', into yoghurt-covered raisins, nutrient bars, chocolate bars, or tablets. Unilever, Hansen, and company Dos Pinos, have developed a probiotic ice cream having multiple health benefits. Many products containing encapsulated probiotic cells are available in a tablet/capsule form or in a powder form. In conclusion, probiotic market has a strong future as the consumers demand is increasing. 
Ozyurt V.H., Ötles S., 2014. Properties of probiotics and encapsulated probiotics in food. Acta Sci. Pol., Technol. Aliment. 13(4), 413-424.

Table 5. Examples of encapsulated probiotics and their applications in various food systems [Burgain et al. 2011]

\begin{tabular}{|c|c|c|c|}
\hline Food & Probiotic strains & ME technology & Materials \\
\hline Cream & L. lactis & extrusion & Ca-alginate \\
\hline Mayonnaise & $\begin{array}{l}\text { B. bifidum } \\
\text { B. infantis }\end{array}$ & emulsification & alginate \\
\hline Dry beverage & Bifidobacterium PL1 & spray drying & starch \\
\hline Banana & L. acidophilus & extrusion & $\mathrm{k}$-Carregeenan \\
\hline Soft foods & B. lactis & extrusion & gellan/xanthan gum \\
\hline Tomato juice & L. acidophilus & & Ca-alginate \\
\hline Sausages & L. reuteri & $\begin{array}{l}\text { extrusion } \\
\text { emulsion }\end{array}$ & alginate \\
\hline Sausages & $\begin{array}{l}\text { L. reuteri } \\
\text { B. longum }\end{array}$ & extrusion & alginate \\
\hline $\begin{array}{l}\text { Biscuits } \\
\text { Cranberry and vegetable juices }\end{array}$ & L. rhamnosus & extrusion & whey protein \\
\hline Oranges and apple juices & $\begin{array}{l}\text { L. rhamnosus } \\
\text { L. salivarius } \\
\text { B. longum } \\
\text { L. plantarum } \\
\text { L. acidophilus } \\
\text { L. paracasei } \\
\text { B. lactis }\end{array}$ & emulsification & \\
\hline Chocolate & $\begin{array}{l}\text { L. helveticus } \\
\text { B. longum }\end{array}$ & spray-coating & fatty acids \\
\hline Swine feeding & LAB & extrusion & Ca-alginate \\
\hline Tomato juice & L. acidophilus & extrusion & \\
\hline Chocolate & $\begin{array}{l}\text { L. helveticus } \\
\text { B. longum }\end{array}$ & spray-coating & \\
\hline Fresh cheese & $\begin{array}{l}\text { L. bulgaricus } \\
\text { S. thermophillus }\end{array}$ & extrusion & Ca-alginate \\
\hline Cheddar & B. bifidum & emulsification & k-Carregeenan \\
\hline Fresh & L. lactis spp. lactis & emulsification & $\mathrm{k}$-Carregeenan \\
\hline Crescenza & $\begin{array}{l}\text { B. bifidum } \\
\text { B. infantis } \\
\text { B. longum }\end{array}$ & freze drying & Ca-alginate \\
\hline Cheddar & L. paracasei & spray drying & skim milk \\
\hline Cheddar & $\begin{array}{l}\text { L. acidophilus } \\
\text { B. infantis }\end{array}$ & emulsification & alginate/starch \\
\hline Feta & $\begin{array}{l}\text { L. acidophilus } \\
\text { B. lactis }\end{array}$ & & alginate \\
\hline Kasar & $\begin{array}{l}\text { L. acidophilus } \\
\text { B. bifidum }\end{array}$ & extrusion and emulsification & alginate \\
\hline White brined & $\begin{array}{l}\text { L. acidophilus } \\
\text { B. lactis }\end{array}$ & extrusion and emulsification & alginate \\
\hline Yoghurt & $\begin{array}{l}\text { L. acidophilus } \\
\text { B. longum }\end{array}$ & spray-drying & maltodextrin/gum arabic \\
\hline Yoghurt & L. acidophilus & extrusion & alginate-chitosan \\
\hline Yoghurt & L. casei & extrusion & alginate/pectin \\
\hline
\end{tabular}




\section{REFERENCES}

Amine K.M., Champagne C.P., Raymond Y., St-Gelais D., Britten M., Fustier P., Salmieri S., Lacroix M., 2014. Survival of microencapsulated Bifidobacterium longum in Cheddar cheese during production and storage. Food Contr. 37, 193-199.

Anekella K., Orsat V., 2013. Optimization of microencapsulation of probiotics in raspberry juice by spray drying. LWT - Food Sci. Techn. 50, 17-24.

Annan N.T., Borza A.D., Hansen L.T., 2008. Encapsulation in alginate-coated gelatin microspheres improves survival of the probiotic Bifidobacterium adolescentis $15703 \mathrm{~T}$ during exposure to simulated gastro-intestinal conditions. Food Res. Int. 41, 184-193.

Antunes A.C.E., Liserre A.M., Coelho A.L.A., Menezes C.R., Moreno I., Yotsuyanagi K., Azambuja N.C., 2013. Acerola nectar with added microencapsulated probiotic. LWT - Food Sci. Techn. 54, 125-131.

Burgain J., Gaiani C., Linder M., Scher J., 2011. Encapsulation of probiotic living cells: From laboratory scale to industrial applications. J. Food Eng. 104, 467-483.

Butstraen C., Salaün F., 2014. Preparation of microcapsules by complex coacervation of gum Arabicand chitosan. Carbohydr. Polym. 99, 608-616.

Capela P., Hay T.K.C., Shah N.P., 2006. Effect of cryoprotectants, prebiotics and microencapsulation on survival of probiotic organisms in yoghurt and freeze-dried yoghurt. Food Res. Int. 39, 203-211.

Chandramouli V., Kailasapathy K., Peiris P., Jones M., 2004. An improved method of microencapsulation and its evaluation to protect Lactobacillus spp. in simulated gastric conditions. J. Microb. Meth. 56, 27-35.

Chávarri M., Marañón I., Ares R., Ibáñez F.C., Marzo F., Villarán M.C., 2010. Microencapsulation of a probiotic and prebiotic in alginate-chitosan capsules improves survival in simulated gastro-intestinal conditions. Int. J. Food Microb. 142, 185-189.

Cook M.T., Tzortzis C., Charalampopoulos D., Khutoryanskiy V.V., 2012. Microencapsulation of probiotics for gastrointestinal delivery. J. Contr. Release 162, 56-67.

Cruz A.G., Antunes A.E.C., Sousa A.L.O.P., Faria J.A.F., Saad S.M.I., 2009. Ice-cream as a probiotic food carrier. Food Res. Int. 42, 1233-1239.

Estevinho B.H., Rocha F., Santos L., Alves A., 2013. Microencapsulation with chitosan by spray drying for industry applications: A review. Trends Food Sci. Techn. 31, 138-155.

Fritzen-Freire C.B., Prudêncio E.S., Pinto S.S., Muñoz I.B., Amboni R.D.M.C., 2013. Effect of microencapsulation on survival of Bifidobacterium BB-12 exposed to simulated gastrointestinal conditions and heat treatments. LWT - Food Sci. Techn. 50, 39-44.

Goktepe I., Juneja V. K., Ahmedna M., 2006. Probiotics in food safety and human health. Taylor and Francis, NW.

Guimaraes R.R., Vendramini A.L.A, Santos A.C., Leite S.G.F., Miguel M.A.L., 2013. Development of probiotic beads similar to fisheggs. J. Funct. Foods 5, 968-973.

Heidebach T., Forst P., Kulozik U., 2009. Transglutaminaseinduced caseinate gelation for the microencapsulation of probiotic cells. Int. Dairy J. 19, 77-84.

Heidebach T., Först P., Kulozik U., 2010. Influence of casein-based microencapsulation on freeze-drying and storage of probiotic cells. J. Food Eng. 98, 309-316.

Jiménez-Colmenero F., 2013. Potential applications of multiple emulsions in the development of healthy and functional foods. Food Res. Int. 52, 64-74.

Kailasapathy K., 2006. Survival of free and encapsulated probiotic bacteria and their effect on the sensory properties of yoghurt. LWT - Food Sci. Techn. 39, 1221-1227.

Kim S.J., Chob S.Y., Kimc S.H., Songd O.J., Shind S., Chaa D.S., Park H.J., 2008. Effect of microencapsulation on viability and other characteristics in Lactobacillus acidophilus ATCC 43121. LWT - Food Sci. Techn. 41, 493-500.

Krasaekoopt W., Bhandari B., Deeth H., 2003. Evaluation of encapsulation techniques of probiotics for yoghurt. Int. Dairy J. 13, 3-13.

Lee Y.K., Salminen S., 2009. Handbook of probiotics and prebiotics. John Wiley, NW.

Li X.Y., Chenb X.G., Suna Z.W., Parkc H.J., Chac D.S., 2011. Preparation of alginate/chitosan/carboxymethyl chitosan complex microcapsules and application in Lactobacillus casei ATCC 393. Carbohydr. Polym. 83, 1479-1485.

Makinen K., Berger B., Bel-Rhlid R., Ananta E., 2012. Science and technology for the mastership of probiotic applications in food products. J. Biotechn. 162, 356-365.

Martins E.M.F., Ramos A.M., Vanzela E.S.L., Stringheta P.C., Pinto C.L.O., Martins J.M., 2013. Products of vegetable origin: A new alternative for the consumption of probiotic bacteria. Food Res. Int. 51, 764-770.

Matalanis A., Jones O.G., McClements D.J., 2011. Structured biopolymer-based delivery systems for encapsulation, protection, and release of lipophilic compounds. Food Hydrocoll. 25, 1865-1880.

Nag A., Han K.S., Singh H., 2011. Microencapsulation of probiotic bacteria using $\mathrm{pH}$-induced gelation of sodium caseinate and gellan gum. Int. Dairy J. 21, 247-253. 
Nedovic V., Kalusevic A., Manojlovic V., Levic S., Bugarski B., 2011. An overview of encapsulation technologies for food applications. Procedia Food Sci. 1, 1806-1815.

Nualkaekula S., Lentona D., Cooka M.T., Khutoryanskiy V.V., Charalampopoulos D., 2012. Chitosan coated alginate beads for the survival of microencapsulated Lactobacillus plantarum in pomegranate juice. Carbohydrate Polymers. 90, 1281-1287.

Okuro P.K., Thomazini M., Balieiro J.C.C., Liberal R.D.C.O., Fávaro-Trindade C.S., 2013. Co-encapsulation of Lactobacillus acidophilus with inulin or polydextrose in solid lipid microparticles provides protection and improves stability. Food Res. Int. 53, 96-103.

Pedroso D.L., Thomazini M., Heinemann R.J.B., Favaro-Trindade C.S., 2012. Protection of Bifidobacterium lactis and Lactobacillus acidophilus by microencapsulation using spray-chilling. Int. Dairy J. 26, 127-132.

Pereira A.L.F., Maciel T.C., Rodrigues S., 2011. Probiotic beverage from cashew apple juice fermented with $\mathrm{Lac}$ tobacillus casei. Food Res. Int. 44, 1276-1283.

Pimentel-González D.J., Campos-Montiel R.G., Lobato-Calleros C., Pedroza-Islas R., Vernon-Carter E.J., 2009. Encapsulation of Lactobacillus rhamnosus in double emulsions formulated with sweet whey as emulsifier and survival in simulated gastrointestinal conditions. Food Res. Int. 42, 292-297.

Prasanna P.H.P., Grandison A.S., Charalampopoulos D., 2014. Bifidobacteria in milk products: An overview of physiological,biochemical, exopolysaccharide production, selection, milk products and health benefits. Food Res. Int. 55, 247-262.

Rehaiem A., Belgacem Z.B., Edalatian M.R., Martínez B., Rodríguez A., Mania M., Guerra N.P., 2014. Assessment of potential probiotic properties and multiple bacteriocin encoding-genes of the technological performing strain Enterococcus faecium MMRA. Food Contr. 37, 343-350.
Rivera-Espinoza Y., Gallardo-Navarro Y., 2010. Non-dairy probiotic products. Food Microbiol. 27, 1-11.

Semyonov D., Ramon O., Shimoni E., 2011. Using ultrasonic vacuum spray dryer to produce highly viable dry probiotics. LWT - Food Sci. Techn. 44, 1844-1852.

Shi L.E., Li Z.H., Zhang Z.L., Zhang T.T., Yu W.M., Zhou M.L., Tang Z.X., 2013. Encapsulation of Lactobacillus bulgaricus in carrageenan-locust bean gum coated milk microspheres with double layer structure. LWT - Food Sci. Techn. 54, 147-151.

Sungsoo Cho S., Finocchiaro E.T., 2010. Handbook of prebiotics and probiotics ingredients health benefits and food applications. CRC Press NW.

Trabelsi I., Bejar W., Ayadi D., Chouayekh H., Kammoun R., Bejar S., Salah R.B., 2013. Encapsulation in alginate and alginate coated-chitosan improved the survival of newly probiotic in oxgall and gastric juice. Int. J. Biol. Macromol. 61, 36-42.

Tulumoglu S., Yuksekdag Z.N., Beyatli Y., Simsek O., Cinar B., Yaşar E., 2013. Probiotic properties of lactobacilli species isolated from children's feces. Anaerobe 24, 36-42.

Vasiljevic T., Shah N.P., 2008. Probiotics - From Metchnikoff to bioactives. Int. Dairy J. 18, 714-728.

Vitali B., Minervini G., Rizzello C.G., Spisni E., Maccaferri S., Brigidi P., Gobbetti M., Cagno R., 2012. Novel probiotic candidates for humans isolated from raw fruits and vegetables. Food Microbiol. 31, 116-125.

Weinbreck F., Bodnár I., Marco M.L., 2010. Can encapsulation lengthen the shelf-life of probiotic bacteria in dry products? Int. J. Food Microbiol. 136, 364-367.

Ying D.Y., Schwanderc S., Weerakkodya R., Sanguansria L., Gantenbein-Demarchic C., Augustina M.A., 2013. Microencapsulated Lactobacillus rhamnosus GG in whey protein and resistant starch matrices: Probiotic survival in fruit juice. J. Funct. Foods 5, 98-105.

Accepted for print - Zaakceptowano do druku: 9.06.2014

Received - Przyjęto: 4.12.2014

For citation - Do cytowania

Ozyurt V.H., Ötles S., 2014. Properties of probiotics and encapsulated probiotics in food. Acta Sci. Pol., Technol. Aliment. 13(4), 413-424. 